\title{
Emerging Powers and the Operationalisation of R2P in Africa: The Role of South Africa in the UNSC
}

\author{
John-Mark Lyi \\ National Research Foundation Chair in International Law, University of \\ Johannesburg, Johannesburg, South Africa \\ johnmarkng20o1@yahoo.com
}

\begin{abstract}
There is anxiety over the future of the emerging norm of the Responsibility to Protect $\left(\mathrm{R}_{2} \mathrm{P}\right)$. This anxiety stems from the controversial nature of the first test case of operationalisation of the 'responsibility to react' component of $\mathrm{R}_{2} \mathrm{P}$ carried out by the North Atlantic Treaty Organization in Libya in 2011. The article argues that the Libyan crisis reinforced the claims of states who argue that $\mathrm{R}_{2} \mathrm{P}$ is susceptible to abuse and this has made it difficult to act in Syria. As a way forward, the paper contends that regional organisations in Africa, led by regional hegemons such as South Africa, should take the lead in the implementation of $\mathrm{R}_{2} \mathrm{P}$ on the Continent. Drawing illustrations from Libya, the author maintains that South Africa should leverage its membership of BRICS and other multilateral frameworks to advance the African Agenda at the United Nations Security Council particularly with reference to the operationalisation of $\mathrm{R}_{2} \mathrm{P}$ in Africa. In order to be able to do this, the paper suggests a reappraisal and recalibration of the $\mathrm{R} 2 \mathrm{P}$ implementation framework to give emphasis to regional organisations.
\end{abstract}

\section{Keywords}

$\mathrm{R} 2 \mathrm{P}$ - South Africa - regional organizations - SADC - ECOWAS - AU - UNSC - Libya

[I]n the real world today, the brutal truth is that our choice is not between intervention and non-intervention. It is between intervention that is ad hoc or rules-based, unilateral or multilateral, consensual or deeply divisive. If we are going to get any sort of consensus in advance of crises 
requiring urgent responses, including military intervention, the $\mathrm{R}_{2} \mathrm{P}$ principles point the way forward. ${ }^{1}$

Since the end of World War II, the world has been faced with the challenge of averting the type of human tragedies - massive loss of lives and suffering that characterised the war. Hence the United Nations Charter in the opening paragraph of its preamble, boldly proclaims that it is "determined to save succeeding generations from the scourge of war, which twice in our lifetime has brought untold sorrow to mankind,...."2 This affirmation was followed by a plethora of international human rights and humanitarian law instruments aimed at giving effect to the above object of the United Nations (UN). ${ }^{3}$ Unfortunately, the existence of these human rights treaty obligations was unable to prevent the genocide, ethnic cleansing, war crimes and crimes against humanity that subsequently occurred in Kampuchea, Pakistan, Liberia, Rwanda and

1 R. Thakur, 'Iraq and R2P', 7 Global Dialogue (2005), available online at http://www.world dialogue.org/content.php?id=327.

2 See Charter of the United Nations signed at San Francisco, available online at www.treaties .un.org/doc/Publication/CTC/uncharter.pdf (accessed 20 August 2013).

3 See, for example, the Universal Declaration on Human Rights (UNGA Res 217 A (III) adopted on 10 December 1948; Convention on the Punishment and Prevention of the Crime of Genocide adopted by the UN General Assembly by Resolution 260 on 9 November 1948, available online at http://www.treaties.un.org/untc/Pages//doc/PublicationUNTS/Volume\%2078/ volume-78-I-10221-English.pdf (accessed 20 August 2013); International Covenant on Civil and Political Rights adopted by the UN General Assembly Resolution 2200A (XXI) of 16 December 1966, available online at http://www.treaties.un.org/doc/Publication/UNTS/ Volume\%20999/volume-999-I-14668-English.pdf (accessed 20 August 2013); International Covenant on Economic, Social and Cultural Rights adopted by the General Assembly by Resolution 2200A (XXI) of 16 December 1966, available online at http://www.ohchr.org/EN/ ProfessionalInterest/Pages/CESCR.aspx (last accessed 20 August 2013); the Four Geneva Conventions of 12 August 1949 and their Additional Protocols of 1977 and 2005, available online at http://www.icrc.org/eng/war-and-law/treaties-customary-law/geneva-conventions/ index.jsp (accessed 20 August 2013); the Rome Statute of the International Criminal Court which entered into force on 1 July 2002, available online at http://www.icc-cpi.int/nr/rdonlyres/eagaeff57-52-4f84-be94-0a655eb3oe16/o/rome_statute_english.pdf (accessed 20 August 2013). 
Srebrenica in the last half of the 2oth century. In response, the international community once again began to search for a normative framework for the prevention of mass atrocities. This time, it found expression in the principle of the Responsibility to Protect $(\mathrm{R} 2 \mathrm{P}) .{ }^{4}$ Owing to the fact that most conflicts and the resulting mass atrocities after 1945 had become intra-state rather than interstate, preventing the resulting mass atrocities have implications for the cardinal international law norms of sovereignty and territorial integrity, non-use of force and non-interference. ${ }^{5}$ Thus, the challenge confronting the international community has been how to prevent mass atrocities without infringing these normative foundations of the international legal order. ${ }^{6}$ The emerging principle of $\mathrm{R}_{2} \mathrm{P}$ therefore seeks to resolve the tension between sovereignty and human rights protection by re-conceptualising sovereignty as responsibility. ${ }^{7}$ But even $\mathrm{R}_{2} \mathrm{P}$ itself is not free from controversy either, constantly requiring refining and clarifications about its status, characterisation and operationalisation. Arguably, the most contentious aspect of $\mathrm{R}_{2} \mathrm{P}$ is the 'responsibility to react' particularly the use of military force to protect civilians from mass atrocity crimes. Countries like India, Brazil, China and South Africa as well as many small and weak countries, while expressing cautious support for the doctrine nonetheless warn of its inherent pitfalls and susceptibility to abuse by powerful states. The intervention in Libya is now seen by some as validating this claim. ${ }^{8}$

4 Following the challenge posed to the international community by then UN Secretary General, Kofi Annan, on the need to reconcile the principle of sovereignty with the protection of human rights in the wake of the controversy surrounding NATO's intervention in Kosovo, the Canadian Government set up the International Commission on Intervention and State Sovereignty which published its report in 2001. See International Commission on Intervention and State Sovereignty The Responsibility to Protect: Report of The International Commission on Intervention and State Sovereignty (International Development Research Centre, Ottawa, on, 2001) (hereafter ICISs Report).

5 See J. Chopra and T.G. Weiss, 'Sovereignty is no Longer Sacrosanct: Codifying Humanitarian Intervention', 6 Ethics and International Affairs (1992), 95-117, at 96.

6 Ibid.

7 G. Evans, The Responsibility to Protect (Brookings Institution Press, Washington, DC, 2008), p. 38 .

8 For an analysis of the views of Germany, India, Brazil and South Africa vis-à-vis R2P and the interventions in Libya, see generally The Responsibility to Protect-From Evasive to Reluctant Action? The Role of Global Middle Powers (Hanns Seidel Foundation, Institute for Security Studies, Konrad Adenauer Foundation, South African Institute of International Affairs, Johannesburg, 2012) (hereafter From Evasive to Reluctant Action). 
In this article, I argue that the effective operationalisation of the responsibility to react component of $\mathrm{R}_{2} \mathrm{P}$ lies outside the United Nations Security Council (UNSC) so long as the UNSC remains unreformed in its present unrepresentative and undemocratic composition. As a result of the perception that $\mathrm{R}_{2} \mathrm{P}$ was abused in Libya, the likely paralysis of the UNSC and a host of other well-worn problems that continue to undermine the effectiveness of the UNSC makes it necessary to search for the effective operationalisation of $\mathrm{R}_{2} \mathrm{P}$, particularly in Africa, within the framework of the relevant regional and sub-regional organisations like the African Union ( $\mathrm{AU}$ ). In this regard, countries like South Africa can play important roles given its status as an emerging power.

This paper therefore examines what role South Africa played in Libya and should play in the future as an emerging power crucial for the effective operationalisation of $\mathrm{R}_{2} \mathrm{P}$ in Africa. I argue here that while it is in fact desirable that the UNSC take primary responsibility for the operationalisation of the responsibility to react, Syria once again demonstrates the weaknesses inherent in the system as it currently exists and the need for an alternative approach - where local and regional actors can play a more central role in their regions beyond mere 'gatekeeping.' ${ }^{9}$ This is based on the fact that besides consensus building and legitimacy issues, timeous response to credible threats of mass atrocities, if regional organisations are driven by legitimate regional leaders like South Africa, they could strengthen the operationalisation of $\mathrm{R}_{2} \mathrm{P}$ where the UNSC has proved itself incapable of acting.

In the context of the relationship between the UNSC and regional organisations and the Libyan intervention for example, I argue for the need for South Africa to re-engage within the UNSC in forging a consensus on the redistribution of authority between the UNSC and the AU and other sub-regional organisations in order to operationalise $\mathrm{R}_{2} \mathrm{P}$ in Africa. The focus should be on the nature of the partnership and cooperation between the organisations, emphasising the need to build on the legal and normative framework already developed by the $\mathrm{AU}$ and other African sub-regional organisations like the Economic Community of West African States (Ecowas) and the Southern Africa Development Community (SADC) while addressing the normative gaps between the AU and UNSC approaches to the protection of human rights and maintenance of peace and security in Africa.

9 See A.J. Bellamy and P.D. Williams, 'The New Politics of Protection: Cote d'Ivoire, Libya and the Responsibility to Protect', 87 International Affairs (2011), 825-850, at p. 846. 
Right from inception in 2001, states' support for $\mathrm{R}_{2} \mathrm{P}$ has changed between what one might call " $\mathrm{R} 2 \mathrm{P}$ enthusiasts", " $\mathrm{R}_{2} \mathrm{P}$ indifferent" and " $\mathrm{R}_{2} \mathrm{P}$ detractors". Whereas there are those who believe in the power of the emerging norm to address the scourge of mass atrocity crimes, there are those states holding the view that there is still too much ambiguity about the principle for it to be described as a legal norm. ${ }^{10}$ There are yet others that doubt the practical utility of the principle, and instead, see it as a dangerous concept susceptible to being employed by powerful states as tools for intervention in the internal affairs of weak states. ${ }^{11}$ The divergence of views often bother on the essential normative characterisation, scope and contents of $\mathrm{R}_{2} \mathrm{P}$ and its relationship with other long-standing norms of international law such as sovereignty, noninterference and prohibition of the use of force. ${ }^{12}$

Besides Canada as the major norm entrepreneur of $\mathrm{R}_{2} \mathrm{P}$, quite a number of countries embraced the principle from the very beginning even though some took a more cautious position on the use of force to operationalise it. ${ }^{13}$ In the wake of the Arab Spring of 2011 and the controversial NATO intervention in Libya, some emerging middle powers have used new platforms such as BRICS (Brazil, Russia, India, China and South Africa); IBSA (India, Brazil and South Africa) and GIBSA (Germany, India, Brazil and South Africa) for advancing their views regarding $\mathrm{R}_{2} \mathrm{P}$ operationalisation. Some of these states such as Brazil and Germany do not reject the view that it may be necessary to use force to protect civilians, but they however emphasise the preventive tools of $\mathrm{R}_{2} \mathrm{P}$ especially the non-military instruments of coercion. ${ }^{14}$

10 See, for example, statements by Norway, Liechtenstein and New Zealand among others, U.N. Doc. A/59/PV.88. See also C. Focarelli, 'The Responsibility to Protect Doctrine and Humanitarian Intervention: Too Many Ambiguities for a Working Doctrine', 13 Journal of Conflict and Security Law (2008), 191-213, at pp. 201 et seq.; J. Welsh, C. Thielking and S.N. MacFarlane, 'The Responsibility to Protect: Assessing the Report of the International Commission on Intervention and State Sovereignty', 57 International Journal (2002), 489-512, at p. 489 .

11 See for example, statements of Colombia, Egypt, Algeria and Pakistan among others during the debates at the 2005 World Summit, U.N. Doc. A/59/PV.86.

12 See U.N. Doc. A/59/PV.87.

13 Ibid.

14 See U.N. Doc. S/PV. 5319. See also E. Passarelli Hammann, 'Brazil and R2P: A Rising Global Player Struggles to Harmonise Discourse and Practice' in From Evasive to Reluctant Action, supra note 8, pp. 75-76; Statement by Her Excellency, Maria Luiza Ribeiro Viotti, Permanent Representative of Brazil to the United Nations, at the Informal Interactive Dialogue on the Responsibility to Protect, 23 July 2010, available online at http://www 
The position of Brazil on $\mathrm{R}_{2} \mathrm{P}$ is sometimes ambiguous, if not contradictory. ${ }^{15}$ For example, though expressing support for the principle, Brazil called for more discussions and clarifications by the United Nations General Assembly (UNGA), arguing that whereas every action should be taken through the UNSC, resort to Chapter VII action is unnecessary - that is to say that the operationalisation of $\mathrm{R}_{2} \mathrm{P}$ should be pursued through the complementary implementation of the Three Pillars of $\mathrm{R}_{2} \mathrm{P}$ in a sequential order as developed by the United Nations Secretary General (UNSG). ${ }^{16}$ The implication of this is that in operationalising $\mathrm{R} 2 \mathrm{P}$, in say Libya or Syria for example, Pillars One and Two must have clearly failed before the international community can have recourse to use of force under Pillar Three. The above scenario arguably would have made the intervention in Libya a difficult one to sustain, since, as some argue, avenues for peaceful resolution of the conflict was not sufficiently explored before the UN SC decided to adopt 1973 imposing a "no-fly-zone" on Libya. ${ }^{17}$ Arguably, this conviction influenced Brazil's abstention during the vote on resolution 1973 and Brazil's subsequent proposal of the principle of "responsibility while protecting" (RwP) ${ }^{18}$ Although RwP does not seek to reformulate R2P, it however tinkers with some elements such as the components of Pillar Three of $\mathrm{R}_{2} \mathrm{P}$ and other procedural requirements for its operationalisation. ${ }^{19}$ Further, RwP re-echoes the reservations expressed by some states at the 2005 World Summit that $\mathrm{R}_{2} \mathrm{P}$ was susceptible to abuse. ${ }^{20}$ Nonetheless, Brazil seeks to engraft RwP on $\mathrm{R}_{2} \mathrm{P}$ by setting out procedural requirements to be observed in the operationalisation of $\mathrm{R}_{2} \mathrm{P}$ through which $\mathrm{R}_{2} \mathrm{P}$ and $\mathrm{RwP}$ could evolve together to

.un.int/brazil/speech/1od-mlrv-informal-interactive-dialogue-on-the-responsibiulityto-protect.html (accessed 10 October 2013); Maria Luiza Ribeiro Viotti, Responsibility to Protect-SG Report on The Role of Regional and Subregional Arrangements in Implementing the Responsibility to Protect 12 July 2011, available online at http://www.un.int/brazil/ speeech/11d-mlrv-Responsibility-to-protect-report.html (accessed 10 October 2013).

15 See Passarelli Hammann, supra note 14. See Statement by Luiza Ribeiro Viotti, Permanent Representative of Brazil at the United Nations Security Council, SC/10215, 30 March 2011, available online at http://www.un/News/Press/docs/2011/sc10215.doc.htm (accessed 10 October 2013).

16 Ibid.

17 See Luiza Ribeiro Viotti 'Informal Interactive Dialogue on the Responsibility to Protect' supra note, 14. Maria Luiza Ribeiro Viotti 'Responsibility While Protecting: Elements for the Development and Promotion of a Concept', annexed to the letter dated 9 November 2011 from the Permanent Representative of Brazil to the United Nations to the SecretaryGeneral, A/66/551-S/2011/201, 1 November 2011.

18 Ibid.

19 Ibid.

20 Ibid. 
enable the international community to exercise 'responsibility while protecting' in order to avoid defeating the object of protecting an imperiled civilian population. ${ }^{21}$

Similarly, Germany embraced $\mathrm{R}_{2} \mathrm{P}$ in the ${ }_{2005}$ World Summit Outcome Document (WSOD) and in its foreign policy document, not only accepts its part of this responsibility, but also expressed confidence that $\mathrm{R}_{2} \mathrm{P}$ would be embraced by more countries in the future and shape the way the UN deals with human rights violations, peace and conflict issues. ${ }^{22} \mathrm{R}_{2} \mathrm{P}$ forms an important part of the foreign policy of Germany and it therefore actively promotes the principle. ${ }^{23}$ Yet, Germany's position on R2P, though clear in principle has been less clear in practice especially when the use of force is involved. ${ }^{24}$ For example, Germany abstained from resolution 1973 (along with India, Brazil, Russia and China) insisting that while it supports the principle of protecting civilians from mass atrocities, it believes this objective could be realised through nonmilitary intervention such as political and diplomatic pressure. ${ }^{25}$ Germany not only declined to participate in the use of force in Libya, it also continues to advocate the operationalisation of the principle through non-use of force. ${ }^{26}$ Notwithstanding its commitment to the protection of civilians, Germany consistently maintained this policy position on the use of force throughout the first test cases of $\mathrm{R}_{2} \mathrm{P}$ in Libya and Cote d'Ivoire, and more recently, Syria. ${ }^{27}$

For its part, India supports $\mathrm{R}_{2} \mathrm{P}$ in principle but remains opposed to the use of force for its operationalisation and therefore qualifies this support with a

21 Ibid.

22 See Federal Ministry of Defence "White Paper 2006 on German Security Policy and the Future of the Bundeswehr", available online at http://www.gees.org/documentos/ Document-01746.pdf (accessed 18 October 2013), pp. 43-44.

23 See L. Brozus and J. von Farkas, 'Germany and R2P: Common but Differentiated Responsibility', in From Evasive to Reluctant Action, supra note 8, p. 56.

24 Germany maintains that it is committed to R2P. See U.N. Doc S/PV.5319; S/PV.6650 of 9 November 2011.

25 Germany insisted on strong international economic sanctions but expressed reservations on military intervention citing the risks of such action. See S/PV.6498, 17 March 2011.

26 Although Germany was one of the leading states in NATO's intervention in Kosovo, it has been argued that Germany had participated in that intervention in line with its commitments as a member of NATO. See Brozus \& von Farkas, supra note 23, p. 54.

27 See 'Germany Proceeds with Caution in Syria', available online at http://www.dw.de/ germany-proceeds-with-caution-in-syria-policy/a17050654 (accessed 20 October 2013); J.D. Bindenagel, 'Germany's global role at risk', The Chicago Council on Global Affairs (25 March 2012), available online at http://www.2012summits.org/commentaries/detail/ bindenagel_1 (accessed 28 May 2012). 
caveat - the primary responsibility to protect populations rests with the territorial state:

Since words have meaning, it would be useful to recall that in Para. 139, the international community was enjoined to use appropriate diplomatic, humanitarian and other peaceful means, and I would like to repeat, peaceful means, to help protect populations in the specific situations of genocide, ethnic cleansing, war crimes and crimes against humanity. Willingness to take chapter VII measures can only be on a case-by-case basis and in cooperation with relevant regional organizations with a specific proviso that such action should only be taken when peaceful means are inadequate and national authorities manifestly fail in discharging their duty. ${ }^{28}$

At face value, this view is in consonant with the report of the International Commission on Intervention and State Sovereignty (ICISS) and the wsoD and does not appear to pose any problem. However, the problem is where the territorial state has failed in this duty or is itself the perpetrator of mass atrocity crimes and peaceful means of implementing $\mathrm{R}_{2} \mathrm{P}$ has been ineffective. India's position on how the international community should deal with such circumstance is less clear. If anything, the pattern of India's voting and comments during the debates on resolutions 1970, 1973, 1975 and more recently, those on Syria, suggest India's unyielding pro-sovereignty posture irrespective of its support for the $\mathrm{R}_{2} \mathrm{P}$ principle.

South Africa which is the focus of this paper has been unequivocal in its support for $\mathrm{R}_{2} \mathrm{P}$. South Africa embraced $\mathrm{R}_{2} \mathrm{P}$ from the very beginning and was an advocate of the principle at the 2005 World Summit. ${ }^{29}$ Predicating its views on the experiences of Africa as the stage of so many conflicts and mass atrocities, South Africa argued that while further discussions and refinement may continue on the principle at the UNGA, the World Summit should take some

28 See Statement by Ambassador Hardeep Singh Puri, Permanent Representative of India to the United Nations at the General Assembly Plenary Meeting on Implementing the Responsibility to Protect, New York, 24 July 2009. Emphasis mine. See also I. Hall, 'Tilting at Windmills? The Indian Debate over the Responsibility to Protect after Unsc Resolution 1973', 5 Global Responsibility to Protect (2013), 84-108, at p. 85 .

29 See United Nations General Assembly, 2005 World Summit Outcome Document (GA Res 6o/1) 24 October 2005, available online at http://www.unrol.org/files/2005\%20World\%20 Summit\%20Outcome.pdf (accessed 20 March 2010). 
action because of the importance of $\mathrm{R}_{2} \mathrm{P}$ to Africa. ${ }^{30}$ South Africa's support for $\mathrm{R}_{2} \mathrm{P}$ is aligned to the Common African position on $\mathrm{R}_{2} \mathrm{P}$ as expressed in the $\mathrm{AU}$ Ezulwini Consensus.

In the Ezulwini Consensus, African states made it clear that they are committed to implementing $\mathrm{R}_{2} \mathrm{P}$ through their regional organisation - the $\mathrm{AU}^{3{ }^{31} \mathrm{As}}$ will be demonstrated below, this declaration and the role of states like South Africa in giving effect to it was tested in Libya. As we have seen, amongst the other states and emerging power blocs in which South Africa is a member, there is as yet no consensus on the operationalisation of $\mathrm{R}_{2} \mathrm{P}$ at the UNSC. Given the fact that South Africa might sometimes have to balance its position with these middle powers at different multilateral institutions particularly the UNSC, it is imperative to examine how South Africa has approached this challenge and the implications for its broader African agenda in particular with reference to $\mathrm{R}_{2} \mathrm{P}$ and the maintenance of peace and security in the continent. The remainder of this paper is devoted to this issue. But first, it is helpful to clarify the $\mathrm{R}_{2} \mathrm{P}$ concept.

$\mathrm{R}_{2} \mathrm{P}$ has undergone a transformation from its original conception in the ICISS 2001 report, both in terms of meaning and the recommendations made for its operationalisation. ${ }^{32} \mathrm{R} 2 \mathrm{P}$ involves protection against four basic crimes genocide, war crimes, ethnic cleansing and crimes against humanity and the

30 See Statement by Mr. Xolisa Mabhongo Charge D' Affaires, in the Informal Thematic Consultations of the General Assembly on Cluster III Issues, April 2005, available online at http://www.southafrica-newyork.net/speeches_pmun/view_speech.php? speech $=5561068$ (accessed 28 September2013). Quite unexpectedly, opposition to imposing a legal duty as against a moral obligation on the UN and international community to intervene in situations where the territorial state has failed to discharge its responsibility to protect came from the Us. See the Letter of Ambassador John Bolton, U.s. Representative to the United Nations, to the President of the UN General Assembly, 30 August 2005 .

31 See The Common African Position on the Proposed Reform of the United Nations: The Ezulwini Consensus, Executive Council 7th Extraordinary Session, 7-8 March Addis Ababa, Ethiopia. Ext./EX. CL/2 (VII) 6 (hereafter Ezulwini Consensus).

32 The contours of the principle are articulated in the ICIss Report, supra note 4 . The present legal status of the principle is contained in paragraph 138 and 139 of the 2005 World Summit Outcome Document. 
incitement of these crimes. ${ }^{33}$ However, attempts had been made in the past to stretch the scope of $\mathrm{R}_{2} \mathrm{P}$ to cover cases of natural disasters such as Cyclone Nargis in Myanmar in 2008 and the earthquake in Haiti. ${ }^{34}$ Some commentators had also tried to extend the principle to cover the responsibility to prevent the acquisition of weapons of mass destruction. ${ }^{35}$ The controversy and ambiguity surrounding the meaning and scope of $\mathrm{R}_{2} \mathrm{P}$ is also evident in the four major authoritative documents on the concept, ${ }^{36}$ all of which have divergent positions on some essential components of the concept and differ significantly in many respects. ${ }^{37}$

Against the above background, the process of clarifying the meaning of $\mathrm{R}_{2} \mathrm{P}$ has continued after the WSOD and series of UNSC resolutions continue to make reference to the principle in various contexts. ${ }^{38}$ From the debates at the UN in 2009 and the work of other $\mathrm{R}_{2} \mathrm{P}$ advocates, the scope and content of the principle has become clearer than it was in 2005 and it is now accepted that $\mathrm{R}_{2} \mathrm{P}$ only applies to the four crimes of genocide, ethnic cleansing, war crimes and crimes against humanity. ${ }^{39}$ This process of bringing clarity to the principle has come at a price to the means of operationalising the principle as first conceived by the ICIss. ${ }^{40}$ For example, emphasis is now focused disproportionately on the use of force component of $\mathrm{R}_{2} \mathrm{P}$ as though it were the only and major component of the principle. ${ }^{41}$ Thus, it has been argued that $\mathrm{R}_{2} \mathrm{P}$ lost some of its vital elements in the process of normative clarification and building global consensus for the principle particularly at the World Summit. ${ }^{42}$

33 See paragraph 138 of the wsod.

34 See J. Wong, 'Reconstructing the responsibility to protect in the wake of cyclones and separatism', 84 Tulane Law Review (2009), 219-263, at pp. 246-247.

35 See L. Feinstein and M.-A. Slaughter, 'Duty to Prevent', 83 Foreign Affairs (2004), 136-150, at p. 148.

36 See International Commission on Intervention and State Sovereignty, supra note 4; United Nations, A More Secure World: Our Shared Responsibility, Report of the Secretary General High Level Panel on Threats, Challenges and Change, U.N. Doc. A/59/565; In Larger Freedom: Towards Development, Security and Human Rights for All, Report of the Secretary-General, U.N. Doc. A/59/2005.

37 See C. Stahn, 'Responsibility to protect: political rhetoric or emerging legal norm?', 101 American Journal of International Law (2007), 99-120, at pp. 102-110.

38 See, for example, S/RES/1674 (2006), dealing with protection of civilians in armed conflict, S/RES/1706 (2006) on Darfur.

39 See World Summit Outcome Document, supra note 29, paras 138-139.

$40 \quad$ See Stahn, supra note 37, p. 118.

41 Ibid.

42 See Stahn, supra note 12 at 118. 
To correct this misconception, major advocacy groups have issued further clarifications emphasising that the use of military force is only one of the many components of Pillar Three of $\mathrm{R}_{2} \mathrm{P}$ as calibrated by the report of the UNSG on the implementation of $\mathrm{R}_{2} \mathrm{P}^{43}$ In fact, as it was originally conceived by the ICISS, the single most important element of $\mathrm{R}_{2} \mathrm{P}$ is the duty to prevent and the use of force is intended to be a last resort. ${ }^{44}$

As the cases of Libya, Cote d'Ivoire and Syria show, there is still no consensus on what the responsibility to protect entails with respect to its operationalisation. ${ }^{45}$ So far, debates about $\mathrm{R}_{2} \mathrm{P}$ has almost equated $\mathrm{R}_{2} \mathrm{P}$ with military intervention to protect civilians - a development that could undermine the utility of the principle and likely bring it into the same disrepute and controversy that has characterised the doctrine of humanitarian intervention. ${ }^{46}$ It would appear that this narrow focus on one aspect of the principle is a product of the conceptual disagreements and misunderstandings associated with the need to reach compromise on $\mathrm{R}_{2} \mathrm{P}^{47}$ Although partially responsible for the rapid broad international support $\mathrm{R}_{2} \mathrm{P}$ has received to date, the effect is that these compromises continue to shroud the principle in ambiguity and mask deeper disagreements about what the operationalisation of $\mathrm{R}_{2} \mathrm{P}$ would entail in practice. ${ }^{48}$ As one commentator put it, "[i]nstincts should warn us there must be something wrong as well as right with an idea that can be endorsed by ... strange bedfellows, and there is". ${ }^{49}$ Libya shows that the clarification of $\mathrm{R}_{2} \mathrm{P}$ has implications for the different actors in its operationalisation in Africa and it is particularly important that efforts be geared towards ensuring normative clarity in order to avoid the abuse of the principle as happened in Libya. ${ }^{50}$

43 See International Centre for the Responsibility to Protect 'Clarifying The Third Pillar of the Responsibility to Protect: Timely and Decisive Response 2', available online at http:// www.responsibilitytoprotect.org/Clarifying\%2othe\&Third\&Pillar\%20of\%2othe\%20 Responsibility\%2oto\%2oProtect_Timely\%20and\%2oDecisive\%2oResponse(1).pdf (accessed: 26 May 2012). See also 'R2P tools box', in G. Evans, supra note 7, p. 107.

44 See iciss Report, supra note 4, para. 8.5.

45 See M.-J. Domestici-Met, 'Protecting in Libya on Behalf of the International Community', 3 Goettingen Journal of International Law (2011), 861-889, at p. 884.

46 See The International Coalition for the Responsibility to Protect, supra note 43.

47 See A. Bellamy 'R2P-Dead or Alive?' in From Evasive to Reluctant Action, supra note 8, p. 14.

48 See Stahn, supra note 37, p. 118.

49 See J. Alvarez, 'The schizophrenias of $\mathrm{R}_{2} \mathrm{P}$ ', in P. Alston and E. MacDonald (Eds), Human Rights, Intervention and the Use of Force (Oxford University Press, Oxford 2008), p. 277.

5o Ibid. 
$\mathrm{R}_{2} \mathrm{P}$ has its roots as well as a strong historical significance for the African continent and the vast majority of African states supported the principle at its inception. ${ }^{51}$ The concerns expressed by most African states in relation to $\mathrm{R}_{2} \mathrm{P}$ has to do with the 'responsibility to react' component of the principle, particularly the use of military intervention. ${ }^{52}$ This stems from concerns about abuse of the doctrine of humanitarian intervention in the past - though $\mathrm{R}_{2} \mathrm{P}$ is normatively different from humanitarian intervention - many African states continue to express reservations about the likelihood of abuse. ${ }^{53}$ In the Ezulwini Consensus, African states affirmed that in principle, they are not opposed to the use of force to implement $\mathrm{R}_{2} \mathrm{P}$ when necessary. ${ }^{54}$ However, they insist that while the UNSC remains the principal organ regulating the use of force under the UN Charter, the AU is opposed to the use of force outside Article 51 of the Charter, with the exception that Article $4(\mathrm{~h})$ of the AU Constitutive Act which is normatively similar to $\mathrm{R}_{2} \mathrm{P}$ in terms of the four crimes they seek to prevent now permits the AU to intervene in member states. ${ }^{55}$

It is noteworthy that with reference to the role of the UN and the international community in the operationalisation of $\mathrm{R}_{2} \mathrm{P}$ in Africa, the AU seems to approach the principle more from the First and Second Pillars and the non-coercive elements of Pillar Three, with emphasis on the international community providing assistance to states to enable such states fulfill their responsibility to protect. ${ }^{56}$ Outside this, the AU proposes to pursue operationalising the military intervention dimension of $\mathrm{R}_{2} \mathrm{P}$ through its own mechanism for the maintenance of peace and security in Africa. ${ }^{57}$ These and other concerns have resulted in a doctrinal polarisation of $\mathrm{R}_{2} \mathrm{P}$ as pursued within the UNSC framework and as viewed by the AU. Again, this dichotomy was

51 See E. Luck, 'Sovereignty, Choice and the Responsibility to Protect', 1 Global Responsibility to Protect (2009), 10-21, at p. 15 .

$5^{2}$ See Ezulwini Consensus, supra note 31, p. 6.

53 See, for example, the views of Tanzania, U.N. Doc. A//59/PV.9o, Egypt U.N. Doc. A//59/ PV.86, and Algeria, U.N. Doc. A//59/PV.9o, at the World Summit debates.

54 The AU as a continental organisation has departed from the UN Charter regime by codifying the right of intervention in Article $4(\mathrm{~h})$ of the AU Constitutive Act. EcowAS as a sub-regional organization pioneered this innovation, see Article 10 and 25 of the Protocol Relating to the Ecowas Mechanism for Conflict Prevention Management, Resolution, Peace-keeping and Security, signed at Lome, Togo on 10 December 1999.

56 See Ezulwini Consensus, supra note 31, p. 6. 
borne out clearly by the reaction of President Jacob Zuma of South Africa and prominent Africans who condemned the way Africa was marginalised and subterfuge used to undermine and defeat the AU's efforts to seek a negotiated political settlement to the Libyan crisis - notwithstanding that African states on the UNSC voted for resolution 1973.58

\subsection{South Africa on the UNSC and R2P in Libya}

As stated above, South Africa supported $\mathrm{R}_{2} \mathrm{P}$ from its very inception and once she took her seat as a non-permanent member of the UNSC in 2007, South Africa determined to push forward a policy focusing particularly on the resolution of conflicts and maintenance of peace and security in Africa. ${ }^{59}$ Given its own unique history, South Africa pursues a foreign policy that has at its heart, the notion of Ubuntu - the concept of 'our common humanity'.60 It is the belief of policy makers that South Africa's destiny is intertwined with those of its African neighbours hence it is in the interest of the country to pursue the objective of peace and security within regional and continental frameworks to counterbalance 'colonial legacies and neo-colonial influences'. ${ }^{1}$ To this end, South Africa seeks to find sync with the AU's efforts at maintaining peace and security by cooperating with fellow African states and regional economic communities as building blocks. ${ }^{62}$ Thus, in 2007-2008 when it was first admitted to the UNSC, South Africa was determined to use her position to advance her

$5^{8}$ See L. Mammburu, 'Libyan bombing illegal says Concerned Group', Business Day (24 August 2011), available online at http://www.businessday.co.za/articles/Content .aspx?id=151539 (accessed 20 May 2011).

59 South Africa's African Agenda is articulated in 'Building a better world: the diplomacy of Ubuntu: white paper on South Africa's foreign policy', 13 May 2011, p. 4, available online at http://www.info.gov.za/view/DownloadFinalAction?id=149749 (accessed 15 May 2012) (hereafter Ubuntu).

6o Ibid. Several factors shape South Africa's response to contemporary international issues the change in the global balance of power, the cause and nature of conflicts, and how they affect South Africa, the role of Africa in the anticipated global competition for natural resources and the potential for this to spawn conflict. All these are foregrounded by an African Agenda. Ibid., pp. 16-19. Based on the same history, many expect South Africa's foreign policy to be presaged by its moral commitments. See A. Matshiqi, 'South Africa's Second un Security Council Tenure: The Emerging Powers Dimension' (26 August 2011), Proceedings of Institute for Global Dialogue Roundtable p. 4.

61 Ibid., at p. 20.

62 F. Nganje, 'The UN Security Council Response to the Libyan Crisis: Implications for the African Agenda', 93 Institute for Global Dialogue (2011), 1-4, at p. 3. 
African foreign policy agenda. ${ }^{63}$ However, the implementation of this broad policy thrust has raised several questions and challenges and was put to the test during the implementation of $\mathrm{R}_{2} \mathrm{P}$ in Libya where South Africa, along with the other two African States on the UNSC (Nigeria and Gabon), voted for resolution 1973 which became the legal basis for 'Operation Odyssey Dawn' in Libya. ${ }^{64}$ What is the implication of this and how should South Africa respond to future implementation of $\mathrm{R}_{2} \mathrm{P}$ in Africa?

Following the domestic uproar that greeted NATO's bombing of Libya in enforcement of the no-fly zone, South Africa changed its position by denouncing NATO airstrikes and accusing the West of using resolution 1973 which mandate was to "protect civilians and civilian-populated areas" to pursue regime change in Libya. ${ }^{65}$ It is not clear why South Africa broke ranks with its BRICS, IBSA and GIBSA allies (Brazil, Russia, India, Germany and China who abstained) and voted for resolution 1973 in the first place. Some have argued that it was because South Africa felt the need to redeem itself from the criticisms it received when it voted along with China and Russia against a resolution condemning Zimbabwe and Myanmar for human rights violations during her 2007-2008 UNSC membership. ${ }^{66}$ Others have argued that South Africa wished to be seen as pursuing independent foreign policy choices, ${ }^{67}$ while others argued that South Africa was influenced by the need to maintain a common African position on Libya by voting along with the other African states on the UNSC - Nigeria and Gabon. ${ }^{68}$

Given the historical ties between the ANC and Libya, it stands to reason that South Africa was probably motivated to vote for resolution 1973 because of genuine concerns for civilian protection in Libya when it could

63 See Department of Foreign Affairs, South Africa in the United Nations Security Council 2007-2008, available online at http://www.dfa.gov.za/docs/2009/bookletb5.indd.pdf (accessed 30 September 2013), p. 7 .

64 See sc Res 1973, 17 March 2011.

65 See 'NATO responsible for civilian deaths in Libya: U.S.: Congressman', XinhuaNews (24 August 2011), available online at http://www.news.xinhuanet.com/english2010/ world/2011 08/24/C_131069829.htm (accessed 21 May 2012).

66 See A. Matshiqi, 'South Africa's Foreign Policy: Promoting the African Agenda in the UN Security Council', in South Africa in the UN Security Council: 2011-2012: Promoting the African Agenda in a Sea of Multiple Identities and Alliances (Institute for Global Dialogue, Pretoria, 2012), p. 44.

67 See S. Naidu, 'The Emerging Powers Dimension of South Africa's Second Tenure in the UN Security Council', (Institute for Global Dialogue, Pretoria, 2012), p. 31.

68 See F. Nacerodien, 'South Africa's Second UN Security Council Tenure', supra note 6o, p. 7. 
have abstained. ${ }^{69}$ With the benefit of hindsight now, the German position at the time seems to have squared with conventional wisdom and an objective analysis and response to the crisis both from the perspective of who should respond to the conflict and how. ${ }^{70}$ Whatever the motives, it is beyond doubt that there was a failure of leadership on the part of South Africa particularly at the AU level. For more than four weeks after the crisis began none of the regional powers between South Africa and Nigeria were able to mobilise the $\mathrm{AU}$ to issue a statement. ${ }^{71}$ As the crisis intensified, the AU maintained a studied silence and only issued a communique condemning the Libyan government crackdown on civilians and established the AU ad hoc High-Level Committee on Libya to mediate in the conflict. ${ }^{72}$ Hence, the Us, France and the UK seized the opportunity created by the AU's pusillanimous attitude to engage a more pliant League of Arab States and the Gulf Cooperation Council (apparently more disposed to a regime change agenda) to pave way for NATo bombings. As a commentator rightly puts it,

[t]he... most important point relates to the weakness and inertia displayed by the AU during the Libyan crisis. That the AU was unable to authoritatively speak with one voice and take full charge to resolve a conflict in its own backyard does not portend well for efforts to stem instability or external intervention on the continent. The institutional weaknesses and divisions within the $\mathrm{AU}$, which made it difficult for it

69 See Naidu, supra note 67 , pp. 31-32.

70 See the statement of Germany on resolution 1973, supra note 25.

71 See A. Perry, Africa's Feeble Response to Libya 26 February 2011, available online at http:// www.world.time.com/2011/02/26/africas-feeble-response-to-libya/ (accessed 18 October 2013).

72 See Peace and Security Council 261st Meeting, Addis Ababa, Ethiopia, 23 February 2011, PSC/PR/COMM(CCLXI), available online at http://www.ausitroom-psd.org/Document/PSC2011/261st/Communique/CommuniqueLibya.pdf (accessed 18 October 2013); Peace and Security Council 265th Meeting, Addis Ababa, Ethiopia, 10 March 2011, PSC/ PR/COMM.2(CCLXV), available online at http://www.au.int/en/sites/default/files/ COMMUNIQUE_EN_10_MARCH_2011_PSD_THE_265TH_MEETING_OF_THE_PEACE_ AND_SECURITY_COUNCIL_ADOPTED-FOLLOWING_DECISION_SITUATION_LIBYA .pdf; See Press Statement issued by the Peace and Security Council on 23 March 2011 on the situation in Libya, PSC/PR/BR.1(CCLXVIII), available online at http://www.peaceau .org/uploads/268th-finl-press-statement-libya-en.pdf (accessed 18 October 2013); See The African Union Announces the composition of the Ad hoc High Level Committee on Libya, available online at http://www.au.int/en/sites/default/files/ANN_EN1oMARCH_2011_ PSD_THE_AFRICA_UNION_ANNOUNCES_COMPOSITION_AD_HOC_HIGH_LEVEL_ COMMITTEE_LIBYA.pdf (accessed 18 October 2013). 
to respond expediently to the crisis or even make an unambiguous pronouncement on the no-fly zone, created enough room for opportunistic tendencies to prevail and, arguably, constitute the most serious threat to the peace and stability of Africa. ${ }^{73}$

Not only did the AU fail the test of demonstrating that it was capable of exercising the right to maintain peace and security on the continent which it lays claim to in its Constitutive Act, by acting decisively when necessary, ${ }^{74}$ all the African States that could not mobilise within the AU but ended up voting for resolution 1973 without a commitment from the enforcers to stick with the script of the UNSC mandate bear indirect responsibility for the Libyan incident and the destabilising repercussions it has brought the entire region. It should be pointed out that South Africa did initiate efforts to mobilise support for a negotiated peaceful solution to the conflict within the AU framework, however, the efforts failed for many reasons. First, without the united and unequivocal support of African states (most of whom were divided on the need for Ghadaffi to step down from power), and the AU as a body, the negotiation of the road map got-off to a shaky start. ${ }^{75}$ Secondly, African states and the AU failed to demonstrate that they could muster the political will and commit the necessary material and human resources to the implementation of the road map they were proposing. ${ }^{76}$ Thirdly, although Ghadaffi accepted the road map, the TNC rejected it because it was not clear on the exit of Ghadaffi. ${ }^{77}$ Finally, the NATO $P_{3}$ on the UNSC - the Us, UK and France - were averse to the African proposal and surreptitiously undermined the efforts of South Africa and the entire AU Ad Hoc Committee on Libya. ${ }^{78}$ At this stage, South Africa should have either broken ranks with Nigeria and Gabon and abstained or she could have utilized her BRICS membership to weigh in on Russia and China to veto resolution 1973 and float an alternative resolution essentially along the AU road map. ${ }^{79}$ What lessons can South Africa learn from this experience?

\footnotetext{
73 Nganje, supra note 62, p. 3 .

74 See A. de Waal, 'The Africa Union and the Libya Conflict of 2011', World Peace Foundations (19 December 2012), available online at http://www.sites.tufts.edu/reinventingpeace/2012/12/19/the-african-union-and-the-libyan-conflict-of-2011/ (accessed 12 October 2012).

75 Ibid.

76 Ibid.

77 Ibid.

78 Ibid.

79 See Nacerodien, supra note 6o, p. 9.
} 
Since one of the foci points of South Africa's African Agenda during its tenure in the UNSC was to champion the reform of the UNSC to make it democratic and representative for a fair distribution of power and resources in global governance (an unlikely scenario unless a more radical approach is pursued by the AU), South Africa's focus should be working with the African group and regional blocs and other alliances it had formed such as the BRICS, IBSA and GIBSA, in order to further AU's objectives as far as maintenance of international peace and security in Africa is concerned. ${ }^{80}$ Currently, South Africa's approach is to work within the UN to redefine the AU-UN relationship in order to advance the AU objective that Africans should lead efforts to maintain peace and security in Africa. ${ }^{81}$ Hence, South Africa used its Presidency of the UNSC in January 2012 to push for the adoption of resolution 2033 seeking to redefine AU-UN relationship along the parameters of cooperation and partnership. ${ }^{82}$ It remains to be seen how the same power structure that has resisted reform of the UNSC for so long will permit a new AU-UN relationship that is likely to shift the balance of power in global governance in favour of regional organisations, least of all the $\mathrm{AU}$. It only takes a look at the $\mathrm{AU}$ position on $\mathrm{R}_{2} \mathrm{P}$ as articulated in the Ezulwini Consensus to underscore the often ignored tension between the AU and UNSC in their approaches to the maintenance of peace and security in Africa. ${ }^{83}$ These are legal issues South Africa would have to reconcile with its own position on UN-AU relationship if it is to yield any significant result. The way the UNSC and the AU went about the intervention in Libya once again underscores this unresolved tension.

A corollary of the above is the need for South Africa to pay close attention to the nuances that exist in its own position vis-à-vis its other alliances (IBSA, BRICS and GIBSA) on the one hand, and how it reconciles and navigates these complex interaction of interests, and its own relationship with other African states and the $\mathrm{AU}$ on the other hand in order to advance the African Agenda. ${ }^{84}$ This is more so considering that the policy priorities of these non-African blocs will not necessarily align with those of the AU and other African states, nor is South Africa's concept of the African Agenda necessarily coterminous with

\footnotetext{
8 See Matshiqi, supra note 6o, pp. 45-46.

81 See 'Security Council Commits to Effective Steps to Enhance Relationship with African Union in Coflict Prevention, Resolution, with Unanimous Adoption of 2033 (2012)', available online at http://www.un.org/News/Press/docs/2012/sc10519.doc.htm.

82 See S/RES/2033.

83 See Ezulwini Consensus, supra note 31, on the AU's position on both the UNSC reform, the veto and $\mathrm{R}_{2} \mathrm{P}$.

84 See Matshiqi, supra note 6o, p. 45 .
} 
those of the AU and other African states. ${ }^{85}$ A look at the Brazilian position in $\mathrm{RwP}$ and the $\mathrm{AU}$ position in Ezulwini Consensus reveals some contrasting positions.

First, as pointed out above in the Ezulwini Consensus, Africa maintains that it should take ownership of efforts to maintain peace and security on the continent including where it involves the use of force under R2 $\mathrm{P} .{ }^{86}$ To what extent does the Brazilian RwP square with this position remains to be seen because $\mathrm{RwP}$ is UNSc-leaning. This is one aspect where South Africa will have to reconcile its BRICS position with that of the AU because the $\mathrm{AU}$, tend towards an African-led operationalisation of $\mathrm{R}_{2} \mathrm{P}$ in Africa. ${ }^{87}$ The procedural safeguards outlined in $\mathrm{RwP}$, though could be useful, are more of a reiteration of the principles of humanitarian intervention as it has developed under customary international law and the just war tradition. ${ }^{88}$ However, they never removed the potential for abuse of the doctrine, they will not stop those who would abuse $\mathrm{R}_{2} \mathrm{P}$ as Libya shows and it is unlikely they would be stopped by RwP. To this extent, it would be imperative for South Africa to start building from its African base by working with African states and sub-regional organisations working to put legal and institutional frameworks in place for the maintenance of peace and security in the continent because as a commentator puts it, "[f] or South Africa, defending the African agenda in the UNSC should therefore begin in Addis Ababa and not in New York.'89

$85 \quad$ Ibid., at p. 47 .

86 Ezulwini Consensus, supra note 31.

87 Rwp states that [ $\mathrm{t}$ ] he Security Council must ensure the accountability of those to whom authority is granted to resort to force." See Viotti $R W P$ at 4 at para. 11(i). In this sense the RwP captures South Africa's views for example on the need to hold NATO officials accountable for violations of IHL during the Libyan conflict. See 'South Africa urges to probe NATo's possible human rights violations in Libya', Xinhua News (25 August 2011) available online at http://www.news.xinhuanet.com/english2010/world/2011 08/25/c_131074233. htm (accessed 10 April 2012); T. Mbeki, 'International Law and the future of Africa', available online at http://www.thabombekifoundation.org.za/Pages/ADDRESS-BYTHE-PATRON-OF-THE-TMF,-THABO-MBEKI,-AT-THE-AGM-OF-THE-LAW-SOCIETY-OFTHE-NORTHERN-PROVINCES-SUN-CITY,-NOVEMBER5.aspx (accessed 27 May 2012). Amnesty International and other human rights bodies have also been pushing for those responsible for the unlawful killing of civilians in Libya to be held to account. I have explored this issue elsewhere. See J. Iyi, 'The duty of an Intervention Force to protect civilians: a critical analysis of NATO's intervention in Libya', 2 ACCORD Conflict Trends (2012), $41-48$.

88 See, generally, M. Walzer, Just and Unjust Wars: A Moral Argument With Historical Illustrations, 4th edn (Basic Books, New York, 2006).

89 Nganje, supra note 62, p. 4. 


\subsection{South Africa, the UNSC and R2P after Libya}

As rightly predicted by Bellamy and Williams on the heels of the Libyan crisis, the chances of the UNSC being able to build the necessary consensus for action to protect civilians in the future will depend on how previous missions it sanctioned were implemented. ${ }^{90}$ Also, in her assessment of the intervention in Libya and its implications for $\mathrm{R}_{2} \mathrm{P}$ and the legitimacy of the UNSC, Jennifer Welsh argues, and rightly so in my opinion, that the UNSC has relinquished the notion of impartiality as a rule in its peacekeeping practice. ${ }^{91}$ The consequences are already here. Libya has become the yardstick of operationalisation and the framework of $\mathrm{R}_{2} \mathrm{P}$ discourse. ${ }^{92}$ In spite of the obvious adverse consequences the Libyan intervention has brought to $\mathrm{R}_{2} \mathrm{P}$, some commentators continue to argue that " $\mathrm{R} 2 \mathrm{P}$ is alive and well after Libya." 93 Quite on the contrary, Syria shows that $\mathrm{R}_{2} \mathrm{P}$ is in a coma and no one knows whether it will come out of it alive, and even if it does, severe damage will have been done to its vital organs.

Those who do not see the moral hazards in the selective treatment of Libya and Syria often advance two arguments: That Libya and Syria are two different situations and this justifies the selectivity because non-intervention in one deserving case should not preclude intervention in others. ${ }^{94}$ The second argument is that the problem is not $\mathrm{R}_{2} \mathrm{P}$ but those who misunderstand and misinterpret $\mathrm{R}_{2} \mathrm{P} .{ }^{95}$ The suggestion that the threat to $\mathrm{R}_{2} \mathrm{P}$ comes more from a misunderstanding and misinterpretation than abuse begs the question. Abuse of the concept is no less dangerous than a misapprehension of it. ${ }^{96}$ So far, those

9o See Bellamy and Williams, supra note 9, p. 826 .

91 See J. Welsh, 'Libya and $\mathrm{R}_{2} \mathrm{P}$ ' (23 June 2011), available online at http://www.opencanada .org/features/libya-and-r2p/ (accessed 30 May 2012).

92 See J. Welsh, 'Civilian Protection in Libya: Putting Coercion and Controversy Back into RtoP', 25 Ethics and International Affairs (2011), 255-262, p. 260.

93 See, generally, T.G. Weiss, 'RtoP Alive and Well after Libya', 25 Ethics and International Affairs (2011), 287-292.

94 J. Pattison, 'The Ethics of Humanitarian Intervention in Libya', 25 Ethics \& International Affairs (2011), 271-277, at p. 276.

95 A. de Waal, 'How to End Mass Atrocities', Op-Ed (9 March 2012), available online at: $<$ www .nytimes.com/2012/03/10/oopinion/how-to-end-mass-atrocities.htnl?pagewanted=2 (accessed 29 May 2012).

96 As a stop-gap measure between reform and a UNSC paralysed by veto, it was proposed that the $\mathrm{P}_{5}$ subscribed to a code of conduct under the so-called "constructive abstention" whereby they would refrain from using the veto where their national interest is not at stake. This is even more unlikely now given the Libyan crisis and the resulting consequences for Syria. Ibid. See also ICISs Report supra note 10 at para. 8.29. It is also unlikely 
who have abused $\mathrm{R}_{2} \mathrm{P}$ did not do so because they did not understand what its scope and contents are; they did because by such misinterpretation $\mathrm{R}_{2} \mathrm{P}$ can serve some other purposes just like the doctrine of humanitarian intervention before it. Either way, the deliberate manipulation of $\mathrm{R}_{2} \mathrm{P}$ is part and parcel of the abuse process.

The thorny issue in Libya was how best to protect the civilian populations. Some saw Ghadaffi exit as a necessary precondition for the protection of civilians while others thought otherwise. ${ }^{97}$ Working through the UN, NATO leaders and its allies argued that Ghadaffi had to step down while South Africa, working through the AU sought to pursue diplomacy believing that with negotiations, a ceasefire could be brokered to create room for a political solution and that the only obstacle to this was third party meddling calculated to swing the balance of power in order to determine the outcome of the war. ${ }^{98}$ South Africa working through the AU framework pursued a negotiated political arrangement that perhaps would have protected civilians, but also seen Ghadaffi exit through a process of transition - something the West did not want. The West at the same time, working through the UN sought regime change while also hoping civilians would be protected along the line. Clearly, the actors had divergent motives and objectives and invariably led the organizations they represented the UN and the AU - to work at cross-purposes. Finding a common-ground was near impossible when the motivations and objectives were so diametrically opposed to each other.

Against the strains the Libyan crisis brought to the AU-UN relationship, South Africa's commitment to the implementation of $\mathrm{R}_{2} \mathrm{P}$ in Africa seems to have come under pressure as we saw South Africa's position shift significantly in the Cote d'Ivoire crisis. ${ }^{99}$ Arguably, South Africa rejects any policy that seeks to marginalise the views of Africa and undermine Africa's efforts to find solutions to conflicts in the continent, including the implementation of

that where military intervention has been blocked by a veto in the UNSC, it will receive approval from the UNGA under the 'Uniting for Peace' (so-called Article Six-and-Half) principle. See P. Simons, 'From intervention to prevention: the emerging duty to protect', 7 Global Dialogue (Winter/Spring 2005), available online at http://www.worlddialogue.org/ content.php?id=328.

97 See Welsh, supra note 92, p. 6.

98 President Jacob Zuma of South Africa had alluded to this in his statement. See 'This Time for Africa: Zuma visits Tripoli - Again' France24 News, 29 June 2011 (accessed 24 January 2012).

99 See F. Aboagye, 'South Africa and R2: More Sovereignty and Regime Security than Human Security?', supra note 8, p. 41. 
$\mathrm{R}_{2} \mathrm{P}^{100}$ It can be hoped that South Africa maintains this course of action and in the future avoid such invidious position as it found itself in Libya. Against the backdrop of Libya and Syria, it is imperative that another framework be sought for the operationalisation of $\mathrm{R}_{2} \mathrm{P}$.

\section{Regionalising R2P in Africa: the Role of South Africa in the SADC Sub-Region}

Though writing in relation to weapons of mass destruction, Feinstein and Slaughter rightly pointed out that "[g]iven Security Council's propensity for paralysis, alternative means of enforcement must be considered. The second most legitimate enforcer is the regional organization that is most likely to be affected by the emerging threat." 101 Since the UNSC is often paralysed in the face of mass atrocity crimes, regional organisations could be alternative frameworks for military intervention to operationalise $\mathrm{R}_{2} \mathrm{P}^{102}$ This is so for several reasons. First, an increasing number of regional organisations are making compliance with atrocity crimes prevention criteria for membership. ${ }^{103}$ Secondly, regional organisations' members are signing on to more onerous regional community membership commitments and intrusive treaty human rights obligations at the regional level. ${ }^{104}$ This creates opportunity for leveraging such frameworks for the operationalisation of $\mathrm{R}_{2} \mathrm{P}$. Thirdly, regional organisations can deploy non-military tools under Pillar Three of $\mathrm{R}_{2} \mathrm{P}$ and as demonstrated in the past by ECOWAs, even military intervention as a last resort. Fourth, members of regional organisations might feel more persuaded to comply with and sign on to $\mathrm{R}_{2} \mathrm{P}$ operationalisation instruments they helped create in their regions than resolutions by an organ like the UNSC were they are not represented, notwithstanding their obligations under international law. ${ }^{105}$

There is a voluminous literature on other advantages of regional organisations in the maintenance of international peace and security and they need

\footnotetext{
100 See Statement by President Jacob Zuma, on the Occasion of the United Nations Security Council Summit Debate, available online at http://www.info.gov.za/speech/DynamicActi on?pageid $=461 \&$ sid $=24395 \&$ tid $=53564$ (accessed 21 October 2013$)$.

101 See Feinstein and Slaughter, supra note 35, p. 148.

102 See The International Coalition for the Responsibility to Protect, supra note 43.

103 See J. Iyi 'Humanitarian Intervention and the Responsibility to Protect: Deconstructing Regional Legal and Theoretical Framework for Action in Africa' (PhD Thesis, School of Law, University of the Witwatersrand, Johannesburg).

104 Ibid.

105 Ibid.
} 
not be reiterated here. ${ }^{106}$ The importance of regional organisations in the operationalisation of $\mathrm{R}_{2} \mathrm{P}$ was demonstrated in the Libyan crisis. China claims that it was persuaded to refrain from vetoing resolution 1973 because the AU members on the UNSC supported it. ${ }^{107}$ It is argued that the US, UK and France went ahead with the intervention because it was supported by regional organisations such as the League of Arab States, the Organisation of Islamic Conference and the Gulf Cooperation Council. ${ }^{108}$ Whatever the case, it is arguable that regional organisations are now central to the operationalisation of $\mathrm{R}_{2} \mathrm{P}$ in their regions and as a commentator put it, these regional organisations served as "gatekeepers" in the crisis. ${ }^{109}$ This suggests a change in the roles of regional organisations from one of "followers" to "leaders" in matters of intervention and maintenance of peace and security in their regions. Another commentator even goes as far as arguing that regional consent is perhaps now a prerequisite for UN intervention. ${ }^{110}$ This development will be a fundamental shift because though the collective security arrangement established by Chapter VIII of the Charter reserved a prominent role for regional organisations in the maintenance of peace and security in their regions, it was predicated on the principle of subsidiarity and it is only with respect to peaceful settlement of disputes. ${ }^{111}$ This was a compromise between the universalists and regionalists at the negotiation of the UN Charter in 1945 based on some assumptions. ${ }^{112}$ For obvious reasons, this whole architecture did not quite turn out as envisaged and regional organisations have in response assumed new responsibilities to fill the vacuum, not the least, the operationalisation of $\mathrm{R}_{2} \mathrm{P}$, particularly in Africa by evolving the requisite legal and operational frameworks. ${ }^{113}$

106 See J. Boulden, 'Introduction', in J. Boulden (Ed.), Dealing with Conflict in Africa (Palgrave Macmillan, New York, NY, 2003), pp. 1-9; L. Fawcett, 'The Evolving architecture of regionalization', in M. Pugh and W.P.S. Sidhu (Eds), The United Nations and Regional Security: Europe and Beyond (Lynne Rienner, London, 2004), pp. 11-30; D. Wippman, 'Enforcing the Peace: ECOWAS and the Liberian Civil War', in L.F. Damrosch (Ed.), Collective Intervention in Internal Conflicts (Council of Foreign Relations Press, New York, NY, 1993), pp. 157-203.

107 See Statement by Spokesperson of the Chinese Foreign Ministry, 22 March 2011, available online at http://www.chinaembassy-fi.org/eng/fyrth/t809578.htm.

108 See Bellamy and Williams, supra note 9, pp. 842-843.

109 Ibid., at p. 846.

110 See J. Welsh, 'Solving Syria', available online at http//:www.opencanada.org/features/ solving-syria (accessed 29 May 2012).

111 Ibid. See Articles $5^{2}$ and 53 of the UN Charter.

112 Ibid.

113 This theme is explored in Iyi, supra note 103. 
The above analysis is not to suggest that regional organisations should replace the UN or that they would be able to implement $\mathrm{R}_{2} \mathrm{P}$ without challenges. The problem of hegemonic aspirations, lack of capacity, and multiple memberships are only a few of such challenges. ${ }^{114}$ As observed by a commentator

[f]ailures by the UN to respond to mass atrocities in the past shows it is a fundamentally flawed organization. But to open the door to regionalization would create more problems than it would solve, because the UN is still the only viable global body for collective action. Alternative authorization structures within the UN should be pursued. ${ }^{115}$

Several studies have suggested a co-operation and partnership framework between the UN and regional organisations as the best approach to maximize the utility of regional organisations in their relationship with the UNSC regarding the maintenance of peace and security as established in the Charter. ${ }^{116} \mathrm{It}$ is important to point out the UN is equally plagued by many problems. ${ }^{117} \mathrm{~A}$ comparative study of regional organisations and the UN would reveal that each agency has its area of comparative strengths and weaknesses. ${ }^{118}$ An African sub-regional organisation like EcowAs fares better in willingness to put boots on the ground than even the UN. ${ }^{119}$ The problem of hegemony for example is insignificant because the world and the entire system of global governance is currently built on such superstructure and it is doubtful that decisions are made anymore by consensus or faster at the UNSC than regional organisations in Africa. ${ }^{120}$ The major challenges for regional organisations in Africa are material and financial resources which are all remediable short-term handicaps if the UN and other partners genuinely interested in the operationalisation of

\footnotetext{
114 Ibid.

115 K.M. Haugevik, Regionalizing the Responsibility to Protect: Possibilities, Capabilities and Actualities, No. 2 NUPI Report (NUPI, Oslo, 2008), p. 11.

116 Lessons Learned Unit, Department of Peacekeeping Operations, Cooperation Between the United Nations and Regional Organizations/Arrangements in a Peacekeeping Environment: Suggested Principles ad Mechanisms (UN Security Council, New York, NY, 1999), p. 13.

117 Fawcett, supra note 106, p. 23.

118 See P. Taft and J. Ladnier, Realizing never again: regional capacities to protect civilians in violent conflicts (The Fund for Peace, Washington, DC, 2006), Appendix I, comparing the strengths and weaknesses of several African regional organisations.

119 Ibid.

120 See, generally, H. Kelsen, The Law of the United Nations: A Critical Analysis of its Fundamental Problems (Praeger, New York, NY, 2000).
} 
$\mathrm{R}_{2} \mathrm{P}$ are willing to partner along this line. ${ }^{121}$ The legal and institutional frameworks already exist and all that is needed is to develop the capacity. African subregional organisations could learn from the intervention experiences of each other as well.

For example, until the Mali crisis, EcowAs has been quite proactive in the maintenance of peace and security in its region. It is likely that should a Syriastyle crisis erupt in the West African region, EcowAS could act with UNSC authorisation where possible and without it if necessary to operationalise $\mathrm{R}_{2} \mathrm{P}$. It has also taken the additional step of codifying principles of intervention in its treaties and South Africa could learn from this and further the operationalisation of $\mathrm{R}_{2} \mathrm{P}$ in the Southern African region by pushing for such provision in the SADC Protocol. ${ }^{122}$ The importance of this is highlighted by a comparison of the crisis in Mali and Syria. There is a sharp contrast in how the UNSC responded to Syria and how EcowAs initially responded to Mali and Guinea Bissau. ${ }^{123}$ Bearing in mind that Mali and Guinea Bissau were not near the scale of atrocities in Syria, the degree of paralysis that gripped the UN becomes palpable. $^{124}$

South Africa has been engaged in peacekeeping in Burundi and the Democratic Republic of the Congo. This is an indication that South Africa's commitment to $\mathrm{R}_{2} \mathrm{P}$ would yield more results if she would be more assertive both at the SADC and AU levels. ${ }^{125}$ It would be beneficial both for the UN, regional organisations and the task of civilian protection to allow these regional

121 See Project Ploughshares, 'The Responsibility to Protect: East, Western and Southern African Perspectives on Preventing and Responding to Humanitarian Crises', available online at http://www.dspace.cigilibray.org.jspui/bitsteam/123456789/17368/1/The\%20 Responsibility\%20to\%20Protect\%2oWorking\%2oPaper.pdf?1 (accessed 6 May 2012), pp. 19-21.

122 See J. Iyi, 'The Legal Framework for Sub-regional Humanitarian Intervention in Africa: A Comparative Analysis of ECOWAS and SADC Regimes', 2 SADC Law Journal (2012), 281-303, at p. 300 .

123 ECOWAs has moved swiftly to deploy a small military contingent to Mali and Guinea Bissau already, see http://www.bbc.co.uk/news/world-africa-1786466 (accessed 17 May 2012).

124 The fact that it was the French that eventually intervened in Mali rather than Ecowas is attributable to two main reasons: first, ECOWAS chose to wait for UNSC authorisation in the hope that obtaining such authorisation would make Western countries more willing to provide the much needed financial and logistic support for the intervention. The authorisation was delayed for almost a year and half. See 'Mali Crisis: UN Defers Decision on ECOWAS Force', $B B C$ News (15 July 2012), available online at http://www.bbc.co.uk/ news/world-africa-18728950 (accessed 18 October 2013).

125 See Nganje, supra note 62, p. 3. 
organisations the autonomy for the operationalisation of $\mathrm{R}_{2} \mathrm{P}$ in Africa. Each regional organisation could set out its criteria and framework for intervention along clearly defined legal parameters set out in its regional treaties. Of course, not all subregional organisations have the capacity in this regard and each subregion will have to develop its own framework along its unique history and challenges. ${ }^{126}$ EC OWAS intervened in Liberia and Sierra Leone for example and NATO intervened in Kosovo. Certainly not perfect interventions, but the UNSC was paralysed just as it is now in Syria. These are lessons from the past and hard evidence that cannot be ignored about the utility of regional organisations in the search for a framework for the operationalisation of $\mathrm{R}_{2} \mathrm{P}$. If the Arab League took a position that it wishes to intervene in Syria today (assuming it has both the legal framework and military capability to do so), it is doubtful that Russia or China would try to block the intervention or be even interested in doing so. Clearly, the obstacle is because the forum for decision-making is the UNSC where other interests than civilian protection take priority. In the Libyan intervention, there were fears of 'occupation force' but such terms as 'occupation force' 'imperialist agenda' 'neocolonial interventionist policy' are only raised where the West is perceived to be behind the intervention but hardly where regional actors are involved. For example, EcowAs deployed small contingents to Mali and Guinea Bissau and the target countries hardly raised fears of occupation force or imperialist agenda. The fear of being viewed as an 'occupation force' in Libya may be one factor why the UNSC refused boots on the ground even though ground troops would have been the most effective means of protecting civilians with minimum civilian casualties. ${ }^{127}$

Since the 1990s, efforts aimed at improving the international community's response to mass atrocities has advocated greater role for regional organisations. ${ }^{128}$ In his Agenda for Peace the UNSG called for greater UN-regional organisations cooperation. ${ }^{129}$ The boldest attempt was the recommendation of the ICISs that regional organisations be able to intervene without UNSC authorisation where the UNSC is deadlocked. ${ }^{130}$ The hard cases for

\footnotetext{
126 See UN Lessons Learned Unit, Cooperation between the United Nations and Regional Organizations, supra note 54 at 12.

127 See J. Iyi, 'The Duty of an Intervention Force to Protect Civilians: A Critical Analysis of NATO's Intervention in Libya', 2 Conflict Trends (2012), 41-48, at p. 44.

128 See Boutros Boutros-Ghali An Agenda for Peace: Preventive Diplomacy, Peacemaking and Peacekeeping, Report of Secretary-General A/47/277-S/24111, 17 June 1992; Report of the Panel on United Nations Operations A/55/305-S/2000/309, 21 August 2000 (also called the Brahimi Report).

129 Ibid., paras 64-65.

130 See Stahn, supra note 37, p. 104.
} 
$\mathrm{R}_{2} \mathrm{P}$ would not be the Rwanda-type genocides because in such cases, it would be relatively easy to mobilise for intervention if the considerations are only the resources needed to intervene. The real difficult cases would be where a $\mathrm{P}_{5}$ has a national interest at stake in blocking intervention as we see in Syria. This is the real challenge for the UNSC and resolving it within the UNSC will likely be difficult. It will most likely be resolved and intervention possible within and by the relevant regional organisations outside of UNSC.

South Africa generally pursues the option of negotiated settlement in African crises - Zimbabwe, Cote d'Ivoire and Libya - but these have not always been successful. ${ }^{131}$ The failure of these efforts has more to do with lack of proactive sub-regional and regional leadership on the part of South Africa than anything else. ${ }^{132}$ Though having the financial and military capacity, South Africa has been reluctant to deploy these resources effectively even within the Southern African region. For example, despite the original initiative to establish the 1996, SADC Organ on Politics, Defence and Security, this framework has been allowed to fall into disuse. ${ }^{133}$ The principles of the Organ provides for inter alia: (c) achievement of solidarity, peace and security in the region; (d) observance of human rights, democracy and the rule of law; (g) military intervention of whatever nature shall be decided upon only after all possible political remedies have been exhausted in accordance with the Charter of the OAU and the United Nations. ${ }^{134}$ This can be legal tools for operationalisation of $\mathrm{R}_{2} \mathrm{P}$. South Africa can provide the leadership for the operationalisation of $\mathrm{R}_{2} \mathrm{P}$ using this framework to build and develop an enforcement mechanism.

South Africa should realise that the less intrusive and non-coercive tools of $\mathrm{R}_{2} \mathrm{P}$ it pursued in Libya would not receive equal attention as the military option at the global level. Pillar Two will only receive adequate attention where there is a genuine commitment to the protection of civilians for its own sake because, in such cases, alternative approaches usually ignored in other less altruistic missions readily present themselves - creation of humanitarian corridors, safe havens, negotiated settlement that does not pose existential threat to the actors and so on - all become viable solutions to a conflict. ${ }^{135}$ South Africa can use its membership of the various power blocs to ensure that external

\footnotetext{
131 See Matshiqi, supra note 6o, p. 43.

132 See Nganje, supra note 62, p. 5 .

133 Extraordinary SADC Heads of State and Government Communiqué Gaborone, Botswana, 28 June 1996.

134 Ibid.

135 See De Waal, supra note 95.
} 
powers pursuing national interests under the guise of operationalising $\mathrm{R}_{2} \mathrm{P}$ in Africa do not get the support of the international community. 136

Furthermore, the $\mathrm{R}_{2} \mathrm{P}$ schema should be recalibrated to include that where a state is manifestly failing or is unable or unwilling to discharge its responsibility to protect, then the responsibility passes to the relevant regional organisation. Where the regional organisation is unwilling or unable, it should pass to the UN. ${ }^{137}$ In such cases, the regional organisation should be able to act without prior UNSC authorisation. However, where there does not exist a regional organisation, the responsibility should automatically pass from the State to the UN. This will serve the purpose of assigning responsibility to pre-determined actors and avoid the situation where the responsibility is said to pass from the State to the international community - a forum where you have regional organisations and UN as principal actors, but where, because of lack of clarification as to who should be doing what, action is never taken or when taken, it is usually too little too late. There should be clarity about who should act and when and this will help in establishing accountability for failure to act by the international community at any material point in time. Hence there should be a flexible timeline within which each actor is expected to act before the responsibility passes depending on the circumstances.

\section{6}

\section{Conclusion}

One of the lessons of the intervention in Libya is that the mere existence of precautionary principles of $\mathrm{R}_{2} \mathrm{P}$ is no sufficient firewall against abuse. Beside norm clarification tough questions must be asked and difficult and sometimes unpopular decisions will have to be made. If the original meaning of $\mathrm{R}_{2} \mathrm{P}$ as conceived by the ICISS is the protection of civilians from mass atrocities, what is the connection between this objective and the objective of meeting the legitimate aspirations of a people - interpreted as regime change in Libya and Syria - and which should be the focus and priority of the international community particularly the UNSC in operationalising $\mathrm{R}_{2} \mathrm{P}$ ? This question needs to be answered if $\mathrm{R}_{2} \mathrm{P}$ is to be revived from the current disrepute into which it has fallen. With the way resolution 1973 was implemented, it will become difficult to build consensus in future situations for UN missions however compelling the case may be. To avoid this situation, regional organisations should play a central role in such interventions and where such regional organisation

\footnotetext{
136 Ibid.

137 See Iyi, supra note 104.
} 
lacks the capability, a multilateral mission under UN control should be preferable. The UN should be more circumspect in authorising or sub-contracting extra-regional actors to enforce $\mathrm{R}_{2} \mathrm{P}$ in Africa. The relevant regional organisation should be encouraged to develop an intervention legal framework so as to lessen the burden on the UN.

Arguably, if Syria were in Africa, it is unlikely that South Africa would vote for another resolution 1973 today. The picture of bombs dropping on Ghadaffi's residence and killing civilian family members including his grandson, the bloodied face of Ghadaffi being tortured raise concerns about the implementation of the mandate. Arguably, this explains why the UNSC has been paralysed in the Syrian crisis despite the scale of war crimes and crimes against humanity committed there. The view that $\mathrm{R}_{2} \mathrm{P}$ triumphed and is in good shape after Libya is a deeply flawed assessment. Flawed not because Syria is fundamentally different from Libya as such, but because the ghost of Libya haunts Syria and to deny it is to ignore the mistakes that were made in Libya, and ignoring those mistakes leaves us susceptible to repeating them. For now, the approach of military intervention as a tool for the operationalisation of $\mathrm{R}_{2} \mathrm{P}$ in Africa needs regional approach and South Africa can take the lead both within SADC and the AU. The UNSC must discard the notion that $\mathrm{R}_{2} \mathrm{P}$ and civilian protection are only realisable if they result in international criminal prosecutions, elections and democracy all of which pose existential threats to the dictators. ${ }^{138}$ Given this scenario and with Ghadaffi dead, Charles Taylor in jail, Hosni Mubarak in jail, Ben Ali on exile, Laurent Gbagbo awaiting trial, Bashar al-Assad has no incentives to negotiate. Clinging on to power at all costs is his only chance of survival and he surely knows it. He would rather go down fighting than risk leaving power and face international criminal justice and as long as the UNSC remains paralysed, he may yet have his way.

\section{Acknowledgements}

I am grateful to the anonymous reviewers for their useful comments. I wish to thank the Institute for Security Studies for inviting me to participate at a conference on 'The Responsibility to Protect: Views from South Africa, Brazil, India and Germany' Institute for Security Studies, Pretoria, 7 June 2012, where this paper was first presented.

138 Ibid. 